\title{
Nutrition for Enhancing Bone Volume in Mice
}

\author{
Junji Ohtani, Fujita Tadashi, \\ R.A. Marquez Hernandez, Toshitsugu Kawata, \\ Masato Kaku, Masahide Motokawa and Kazuo Tanne \\ Department of Orthodontics and Craniofacial Developmental Biology, Hiroshima \\ University Graduate School of Biomedical Sciences, Hiroshima, \\ Japan
}

\section{Introduction}

It is well known that postmenopausal osteoporosis is related to severe decreases in the serum estrogen levels. Estrogen deficiency produces an imbalance in the bone remodeling balance which is associated with a reduced bone volume and higher fracture risk. Androgen deficiency also produces osteoporosis by directly affecting bone cells. In addition, androgen was demonstrated to be present during the fetal period, and it is considered to play an essential role in the sexual differentiation of males. Therefore, both sex hormones, androgen and estrogen, are great important for bone homeostasis not only in females but also in males. This is further supported by the fact that both males and females express androgen receptor $(\mathrm{AR})$, estrogen receptor-alpha $(\mathrm{ER} \alpha)$ and estrogen receptor-beta (ER $\beta)$. Androgen and estrogen react with the AR and ER $\alpha$ and ER $\beta$, respectively. It is thus speculated that they mutually regulate themselves during bone development and remodeling.

Up to present, various studies have examined the roles of estrogen and its receptors to explore potential methods for preventing or treating postmenopausal osteoporosis (Judd et al., 1983; Kousteni et al., 2002; Martin-Milan et al., 2010; Pietschmann et al., 2008). Recent clinical studies have reported that the prevention of hip bone fractures and vertebral deformities is highly pertinent to improving the quality of life for older people (Chang et al., 2004; O'Neill et al., 2009). To avoid these incidents, we have to try to achieve adequate peak bone mass during adolescent growth, it is also important to understand the bone growth, because this is currently an under-investigated area. In adult animal experiments, orchiectomy and ovariectomy reduced both the bone volume and density. Furthermore, the bone volume loss was induced not only in the long bones but also in the mandibular condyles (Fujita et al., 2001). In addition, we have reported that these phenomena were also shown in immature mice (Fujita et al., 2006). Therefore, the influence of sex hormones on bone remodeling has been demonstrated in the craniofacial region. In orthodontic and orthopedic treatment, it is especially, difficult to predict bone growth including craniofacial and mandibular growth during adolescence. The full nature of bone growth, in association with sex hormones remains to be fully elucidated.

The ratio of osteoporosis patient in Japan based on the diagnosed by Japanese society for bone and mineral research is reported $24 \%$ of over fifty-year-old people and it is indicated the number of patients is higher than those in USA and European countries (Orimo, 2000). 
Therefore, we all recognize osteoporosis is one of serious social problems in Japan. This fact indicates that the influences of sex hormones on bone metabolism are very complicated, and the mechanism is very difficult to be understood.

Peak bone mass, in general, is acquired from childhood to adolescence, but $35 \%$ of cortical bone and $50 \%$ of trabecular bone are lost gradually thereafter after. The importance of preventive medicine thus has been gradually recognized in the field of orthopaedic surgery with a concept that peak bone mass is to be increased and saved during childhood as much as possible (Lapauw et al., 2009; Kaufman, 2009). Such an idea has been attracting a special attention in the field of clinical medicine for the prevention of osteoporosis. The importance of normal development and growth of bone until adolescence has also been reported (Karlsson et al., 2008; Wang et al., 2008). This fact suggested that if we are able to increase the peak bone mass during adolescence as possible by providing some effective nutrition for increasing bone volume, it may leads to prevent the risk and to delay the appearance of osteoporosis.

According to the prevention and treatment of guideline in osteoporosis, it was recommended to intake daily dose of calcium is higher (Rosen \& Gallagher, 2011). However, the amount of calcium intake is approximately $500 \mathrm{mg}$ per one day in practically, and even added the consumption applied by supplement, could not reach daily objective intake.

A newly developed snack used in our experiments contains appropriate amounts of minerals (calcium and magnesium ) and casein phosphopeptide (CPP) as well as soybean isoflavone which has a sex hormone-like action, which is recognized as a specified food for health, is also included. The objective of this chapter was to introduce the effects of bone remodeling including bone volume, density and strength in osteoporosis and healthy growing mice fed a special composition nutrition.

\section{Nutrition}

\subsection{Function of nutrition}

Recently, it was focused on the prevention of osteoporosis and life style related disease like a diabetic and heart disease. Under such situation, people are well considered the food function. It is well known that the function of foodstuff has mainly for nutrition and taste. Additionally, it has also the important function as a decreasing of risk in some disease. The development of foodstuff which has the specific function for living body adjustment is going forward actively in nowadays, therefore the daily food which we intake were diversify. Now it was reported that there are detected and demonstrated in some nutrition that the function of anti-thrombosis, anti-oxidation, encouragement to assimilate calcium, controlling of blood pressure and improvement of cholesterol readings as a food for special health uses and Japanese government had approved it (Yamada et al., 2008). For example, beta-carotene was known as a great nutrition because of its essential function, foodstuff factor as a provitamin, taste factor by its color in vegetable and fruit, and the role of antioxidation (Kim et al., 2010).

\subsection{Casein phosphopeptide}

$\mathrm{CPP}$ is also well known as a factor of encouragement to assimilate calcium. Milk and dairy products contains CPP together with functional protein like a milky basic protein and lactoferrin. Casein as a milk protein is a protein containing phosphoric acid, and is decomposed into oligopeptide of various sizes by the digestive enzyme. It became 
clarified that special protein containing many phosphoric acid called CPP. Generally, calcium is the fifth abundant element by mass in the human body, where it is a common cellular ionic messenger with many functions, and serves also as a structural element in bone. And it has four stable isotopes $\left({ }^{40} \mathrm{Ca},{ }^{42} \mathrm{Ca},{ }^{43} \mathrm{Ca}\right.$ and $\left.{ }^{44} \mathrm{Ca}\right)$ plus two more isotopes $\left({ }^{46} \mathrm{Ca}\right.$ and $\left.{ }^{48} \mathrm{Ca}\right) .97 \%$ of naturally occurring calcium is in the form of ${ }^{40} \mathrm{Ca}$ which is a one of daughter products of ${ }^{40} \mathrm{~K}$ decay, along with ${ }^{40} \mathrm{Ar}$ (Mueller \& Boehm, 2011; Skulan \& DePaolo, 1999). Calcium is hard to be absorbed in human body since it combines with negative ion such as a phosphoric acid in a small intestine. However, CPP prevents own insoluble and promote its efficiency of absorption in a small intestine due to a part of serine residue is phosphorylated and the ionic bond of CPP is carried out to calcium with the negative ion of phosphate group.

Moreover, the function in the promotion of absorption efficacy of CPP, it is positively applied in the form of casein phosphopeptide-amorphous calcium phosphate (CPP-ACP), and is widely well-known as Recaldent. CPP from the major protein of milk have the remarkable ability to stabilize calcium, phosphate and fluoride ions as water soluble amorphous complexes that provide bioavairable calcium, phosphate and fluoride ions to the tooth. Animal and short-term human clinical trials to repair early staged of tooth decay by replacing the calcium and phosphate ions lost due to decay (Reynolds, 2009; Llena et al., 2009). Long-term controlled clinical trials also have demonstrated the efficacy of CPP-ACP is slowing the progression of dental caries and in regressing early stages of tooth decay (Andersson et al., 2007; Morgan et al., 2008). Moreover, it was reported that it is effective rather than the $500 \mathrm{ppm}$ sodium fluoride paste which the dentists have used conventionally for the purpose of prevention of tooth decay (Zhang et al., 2011; Altenburger et al., 2010).

On the other hand, it was reported that the calcium in food exists $50 \sim 60 \%$ in milk, approximately $20 \%$ in small fish and approximately $30 \%$ in vegetable. But, absorption efficacy of calcium in human body is not much excellent. Therefore, CPP is further developed as "food suitable for the people of calcium shortage" such as suger-free gum, tooth cream, dairy milk and another drink and Japanese tofu. However, with such professional tool, food and drink form, we speculated that it will be probably difficult to take freely and daily for the purpose of increasing the absorption efficacy of calcium.

\section{Animal study}

\subsection{Materials and methods}

Fifty male and fifty female C57BL/6J mice of twelve-week-old and thirty male and thirty female C57BL/6J mice of five-day-old (Jackson Laboratory, Bar Harbar, ME, USA) were used in this experiment and divided respectively into eight groups with ten in each sex. In the experimental groups, orchiectomy (ORX) and ovariectomy (OVX) were performed for ten mice of twelve-week-old in each gender at the beginning of experiment to create the situation of osteoporosis model. ORX and OVX were performed by means of a stereoscopic microscope (SZX9, Olympus Optical Co., Tokyo, Japan) under general anesthesia with sodium pentobarbital, whereas the control mice underwent sham operation. The detail of time schedules in adult and growing mice during a series of experiment are shown in Table 1 and 2, respectively. These animals were treated under the ethical regulations defined by the Ethics Committee, Hiroshima University Faculty of Dentistry. 


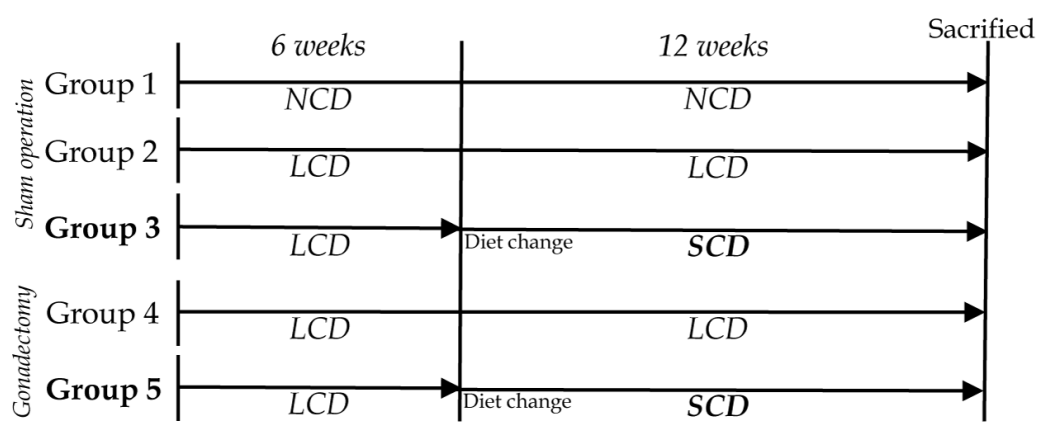

Table 1. Time schedule during experiments in adult mice

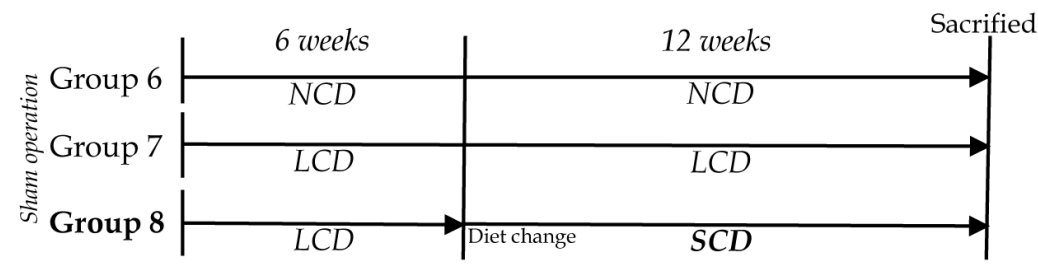

Table 2. Time schedule during experiments in growing mice

We prepared three types of powder diet e.g.: normal calcium diet (NCD, Ca : 0.9\%, Clea Japan Co., Tokyo, Japan), low calcium diet (LCD, Ca : 0.63\%, Clea Japan Co.,) and special diet (SCD, Ca : $0.9 \%$ ) developed as a new bean snack. NCD with $0.9 \%$ calcium was made on basis of objective consumption of calcium intake in humans defined by the Ministry of Health, Labour and Welfare (MHLW) in Japan. LCD including $0.63 \%$ calcium was made on the basis of actual calcium consumption in Japanese. The SCD containing LCD and the newly developmental snack, was supplied as a diet including calcium content same as NCD. The newly developmental snack was composed of calcium, magnesium, CPP and black soybean. As the mainly composition, $1.3 \%$ of calcium, $0.6 \%$ of magnesium, $0.15 \%$ of CPP and $12.8 \%$ of black soybean were included in this snack. NCD was given up to six weeks after sham operation in the group 1 and 6 . Other six groups were given LCD until six weeks after gonadectomy. Six weeks after surgery, group 3, 5 and 8 in each sex were given SCD including the newly developed bean snack.

Eighteen weeks after surgery, all the animals were sacrified under general anesthesia and the femur was fixed with $4 \%$ formaldehyde and prepared for histomorphometric analysis. Peripheral Quantitive Computed Tomography (XCT Research SA, Stratec Medizintechnik $\mathrm{GmbH}$, Pforzheim, Germany) was used to quantify bone density and bone mineral content. Femur was measured at a point $1.4 \mathrm{~mm}$ distal area from chondrocyte growth plate. The cortical bone area was defined as over $690 \mathrm{mg} / \mathrm{cm}^{3}$ threshold and the trabecular bone area was defined as under $395 \mathrm{mg} / \mathrm{cm}^{3}$ threshold. Moreover, bone strength of femur performed by under three point flexural test was also executed in growing mice.

We performed pairwise comparisons (Fisher) to examine the difference in measured values between the groups with a confidence level greater than $95 \%$. All the data are presented as means \pm standard deviations. 


\subsection{In ORX and OVX mice}

Figure 1 shows the photographs of femur section examined by pQCT at the end of experiment. Irrespective of the sex differences, the trabecular bone volume surrounded by the thick cortical bone was maintained at high level in the control groups, in sham operated mice fed NCD in particular (group 1). Meanwhile, trabecular bone volume was decreased moderately in the experimental group 2 with LCD as compared with control mice. Furthermore, the group 4, gonadectomized mice fed LCD exhibited an excessive decrease in bone volume as compared with the groups 1 and 2. On the other hand, the femur section in the group 5, osteoporosis model mice given SCD, presented a prominent recovery of trabecular bone volume.

Male

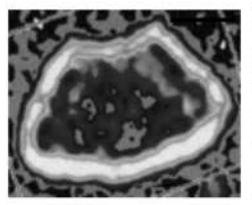

Group 1

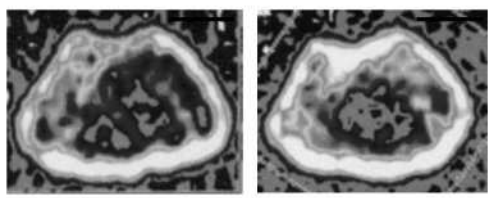

Group 2
Female
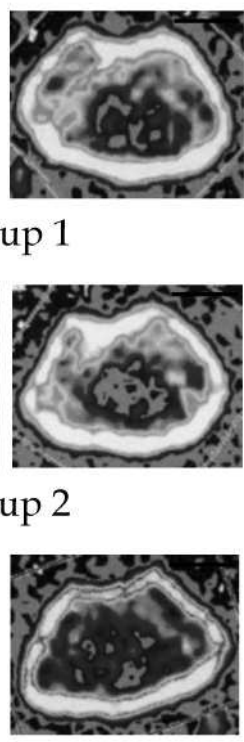

Male

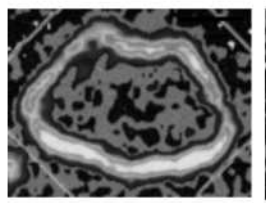

Group 4

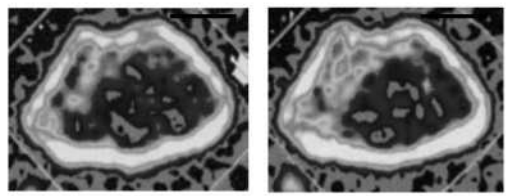

Group 5

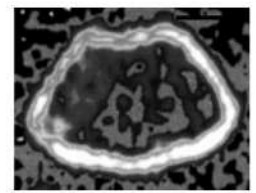

Group 3

(Scale bar : 1.0mm)

Fig. 1. Photographs of femoral section in adult mice.

As a result of pQCT analysis, similar phenomena were observed as mentioned above for the femur structures. The trabecular bone density of gonadectomized mice fed SCD was significantly increased as compared with sham opereated mice given LCD in both genders (Fig. 2). Moreover, the bone density was also significantly increased only in the female mice of group 5 as compared with sham operated mice fed NCD.

For the cortical bone density, different findings from above mentioned results were obtained. Improvement effect was especially revealed in the gonadectomized mice given SCD (group 5) (Fig. 3). Additionally, it was also shown in the sham operated mice fed SCD (group 3) compared with the sham operated mice fed LCD (group 2). These tendencies were observed in both sexes. 

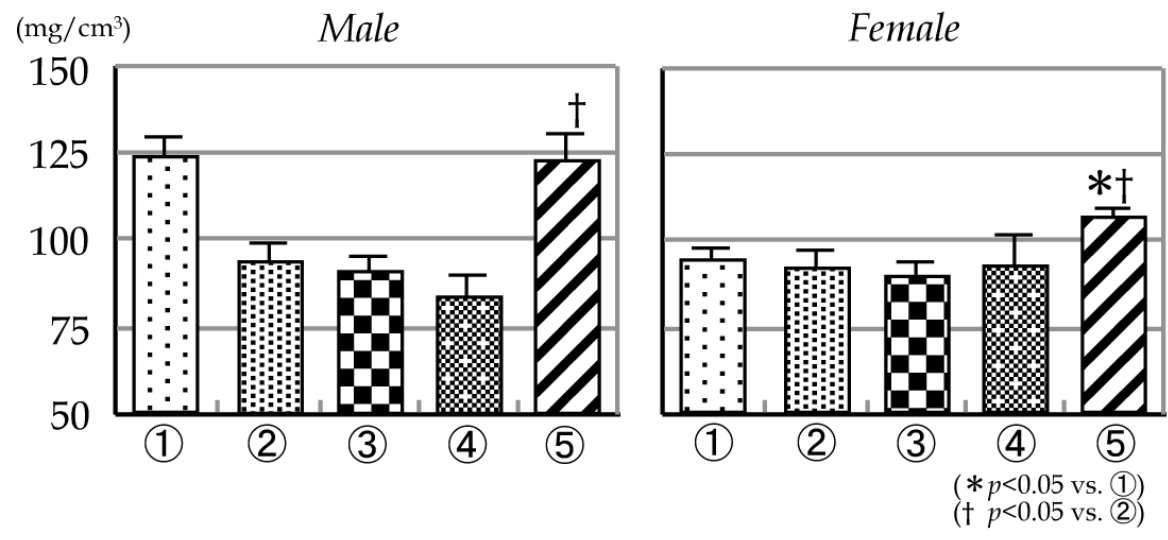

Fig. 2. Trabecular bone density in adult mice
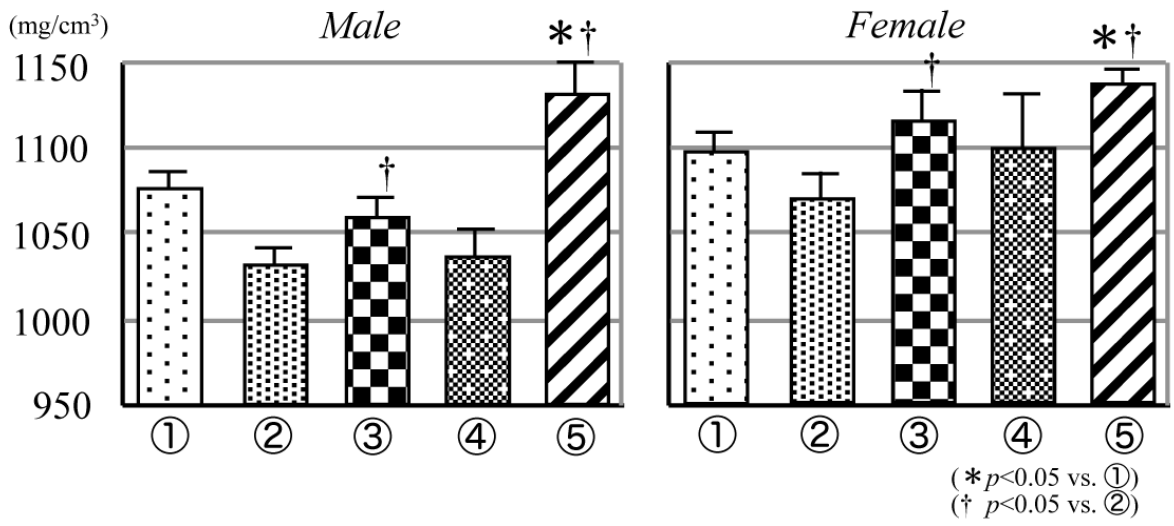

Fig. 3. Cortical bone density in adult mice

Subsequently, the total bone density was apparently increased as compared with other sham operated mice. The reason may be due to SCD supplied to the gonadectomized mice, especially in the female mice (Fig. 4).

For bone mineral content, the groups 3 and 5 mice given SCD exhibited a significant increase as compared with the groups 1 and 2, especially in female mice. It is demonstrated from these findings that the newly development snack is very effective for the improvement of reduced bone quality and controlling of osteoporosis (Fig. 5). 


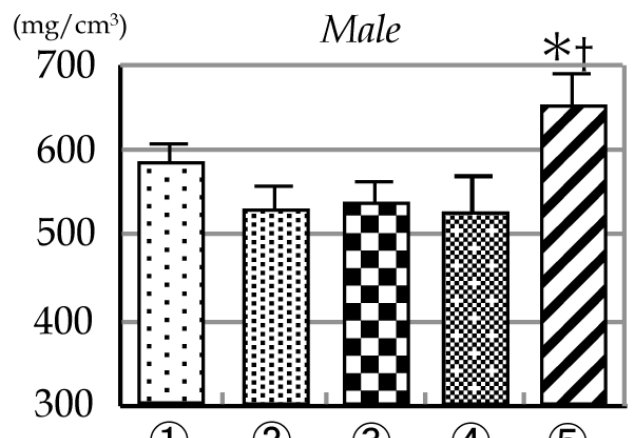

(1) (2)
(3)

(4)
(5)

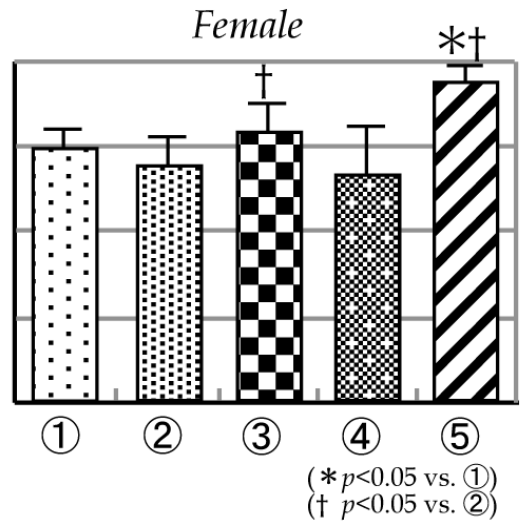

Fig. 4. Total bone density in adult mice
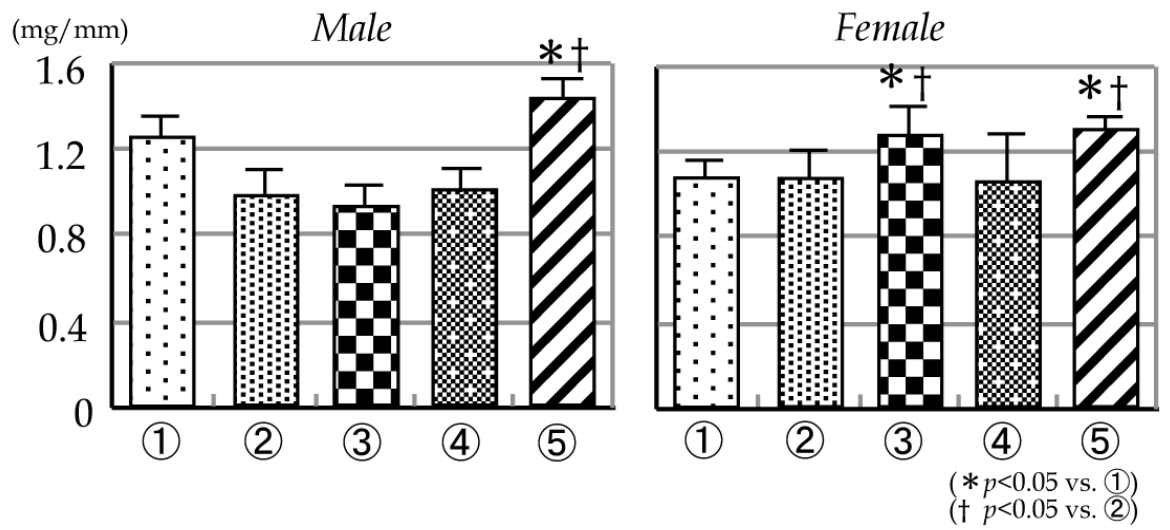

Fig. 5. Bone mineral density in adult mice

\subsection{In young mice}

The results of trabecular bone density were shown in Figure 6. The mice fed NCD revealed around 40 to $50 \mathrm{mg} / \mathrm{cm} 3$ in density, but by the cause of changing food to LCD, it lead to decrease in both sexes. Under such situation, in case of group 8, mice fed SCD from after six weeks to the end of experiment, trabecular bone density showed significantly increased 
compared with mice fed LCD, therefore, there is no significant differences between control mice of group 6 and mice fed food which is changing to SCD after feeding LCD of group 8. In the results of cortical bone density, similar phenomena were observed with trabecular bone density, the cortical bone density of mice fed LCD revealed significantly decreased compared with mice given NCD (Fig. 7). However, by the feed changing to SCD, cortical bone density wasn't getting better as contrasted with the results of trabecular bone density and the results of cortical bone density in adult mice. These tendencies were observed in both sexes. As a result, only in female mice, total bone density also showed the sufficient effect of improvement (Fig. 8). There is no significant difference between group 6 and 8 in male mice.

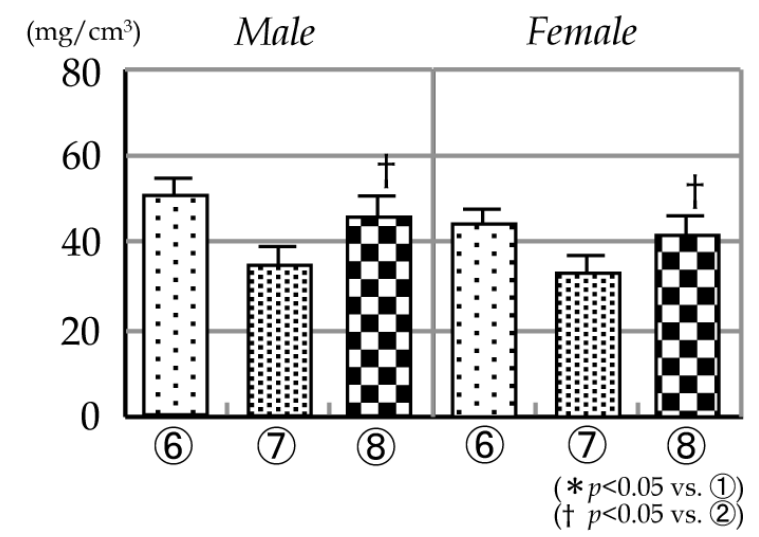

Fig. 6. Trabecular bone density in growing mice

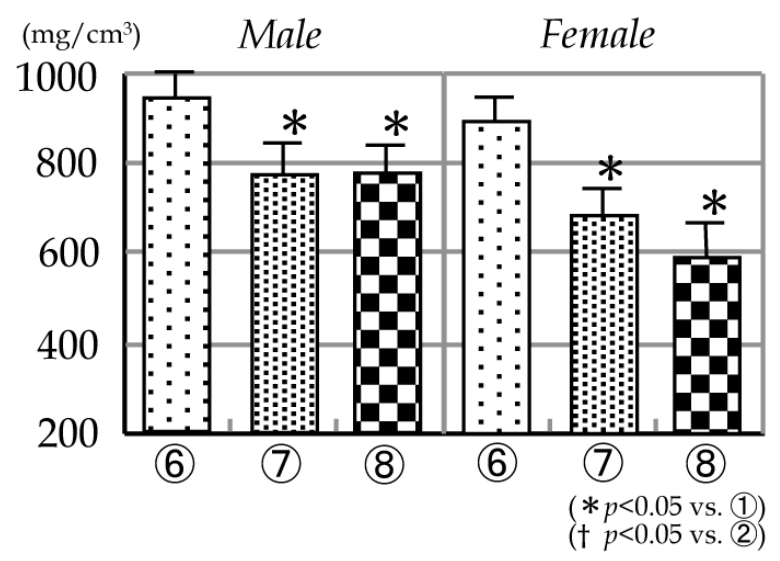

Fig. 7. Cortical bone density in growing mice 


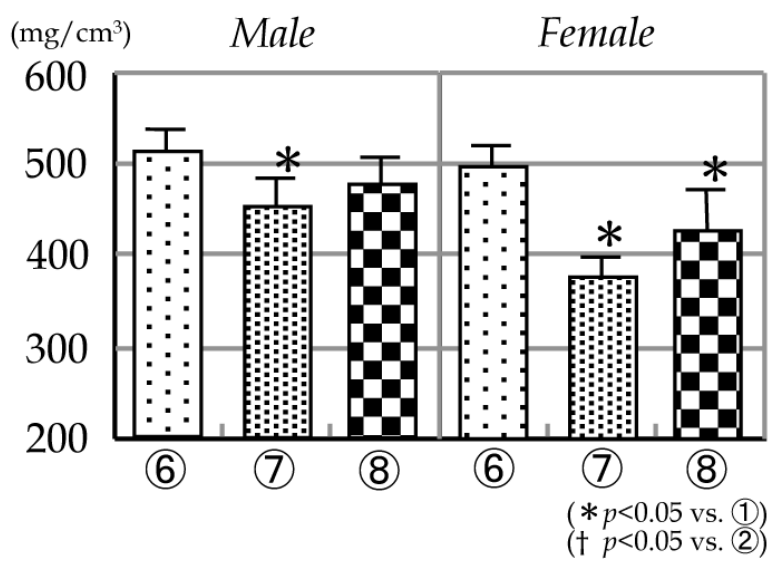

Fig. 8. Total bone density in growing mice

In the results of bone mineral content, Male mice after fed SCD showed no significant differences as compared with the control mice (Fig. 9). On the other hand, female mice of group 7 and 8 showed significantly reduced bone mineral content as compared with mice of group 6.

According to the results of total bone density and bone mineral content, the results of three point flexural test also showed same tendency in male mice (Fig. 10). Meanwhile, although the results of group 8 showed significant lower than the one of group 6 in total bone density and bone mineral content, group 7 and 8 demonstrated same level of group 6 .

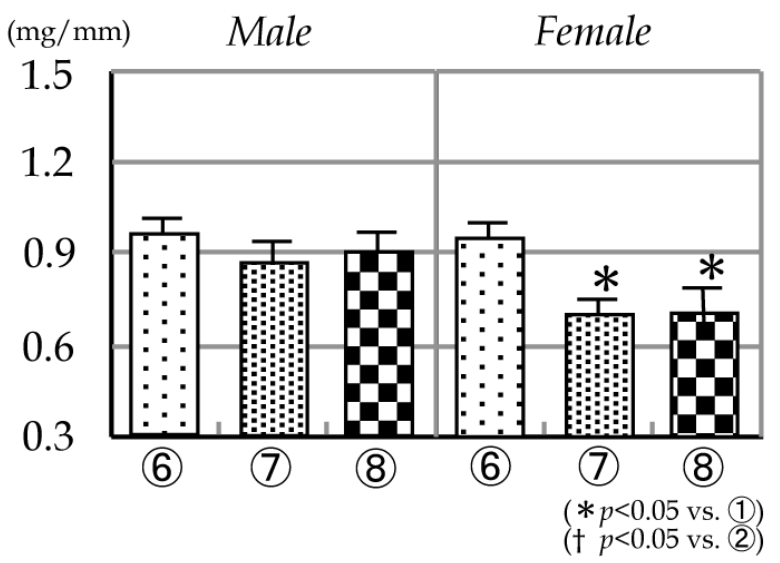

Fig. 9. Bone mineral content in growing mice 


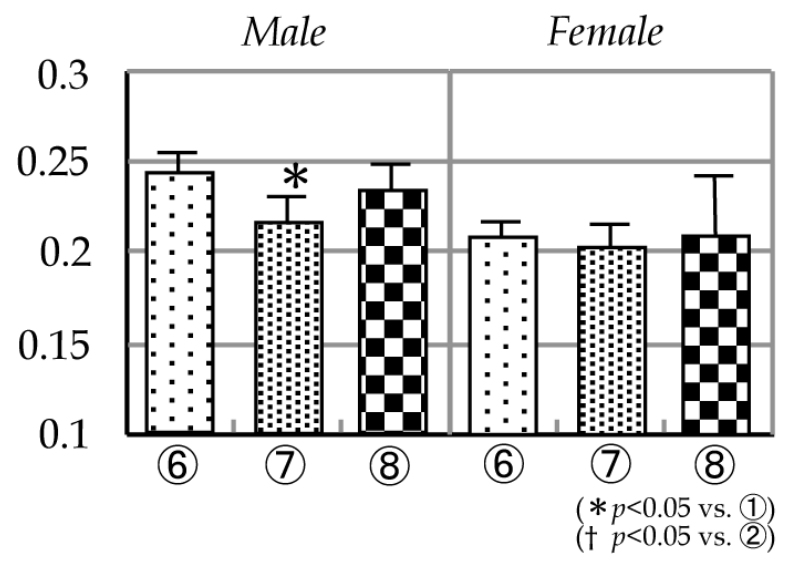

Fig. 10. Three point flexural test in growing mice

\section{Discussion}

Osteoporosis is generally thought of as a disease that affects females, because the prevalence of osteoporosis and the rate of fracture are much higher in postomenomausal females than in older males. However, the absolute number of male patients affected by osteoporosis and fractures has been reported to be large. Older Asian males with low serum estradiol levels also display elevated bone loss and increased risk of fractures similar to the findings in Caucasians (Woo et al., 2011; Moayyeri et al., 2009). The main concern of treatment in osteoporosis research is to prevent bone volume loss by decreasing the progression of bone resorption. Nevertheless, the current knowledge is not sufficient to identify the precise causes of osteoporosis and all of the subjects at risk. As a result, recent studies have indicated that weight-bearing activity and possibly calcium supplements are beneficial if they are begun during childhood, preferably before puberty. The achievement of optimal peak bone mass is important to prevent the risk of bone fracture due to osteoporosis in the future.

The sex hormones are known to be important for the regulation of reproductive functions. They induce sexual differentiation before birth, and sexual maturation during puberty in both genders. They also exert influences on the nervous and cardiovascular systems and are important in the development of the skeletal structure. There are two types of sex hormones, androgens and estrogens. These hormones are secreted mainly from the testis and ovaries. Testosterone can activate the androgen receptor either directly or indirectly after conversion to DHT by $5 \alpha$-reductase. Moreover, it is well known that testosterone is also converted into $17 \beta$-estradiol by $\mathrm{P} 450$ aromatase, which activates the estrogen receptors (alpha and beta). Based on this facts, Ovariectmized and Orchiectomized animals provide an excellent model to study osteoporosis due to estrogen and androgen deficiency in both genders. Both OVX and ORX mice exhibit marked bone loss with increased bone resorption. It was also reported that a loss in bone mineral density in ORX mice was evident between 1 to 4 months post-surgery, and histomorphometric evaluations revealed that this occurred more rapidly and with greater sensitivity in a rat model. 
This snack we had developed was composed of calcium, magnesium, CPP and black soybean. We have examined into body weight and height of all mice during experimental period. However, all mice of supplied food in these measurements were no significant difference compared with the control groups in both sexes (data were not shown). In addition, the amount of all nutrition including supplied food was restrained according the instructions of MHLW in Japan. Therefore, we assumed that supplied special diet food has no occurrence of side effect following snack administration.

It is well known that calcium intake decreases the risk of bone fracture. It was also reported that the calcium supplementation suppress bone formation when magnesium is deficient (Mora \& Gilsanz, 2003). Based on these reports, we designed to mix calcium and magnesium at an appropriate proportion of 2 to 1 . These contents in this snack were compounded to fulfill ninety percentage of the daily-required nutrition defined by MHLW in Japan.

It was also reported that addition of CPP will have a beneficial effect on the absorption of calcium (Dontas \& Yiannakopoulos, 2007). In Japan, CPP was accredited as a food for qualified health uses by MHLW. Accordingly, we add a certain amount of CPP to absorb mineral content easily.

The black soybean contains isoflavone which is widely accepted to have a weak estrogen activity, and to be able to bind estrogen receptor. Actually, Brandi and Miyauchi et al., reported that isoflavone had either effect for the suppression of bone resorption or enhancement of bone formation, affecting directly both osteoclasts and osteoblasts (Brandi, 2003; Miyauchi et al., 1996). In addition, isoflavone was revealed to affect bone metabolism similarly to the sex hormone-like effect in male (Chavarro et al., 2008). Recently, it was also reported that isoflavones have revealed inhibition of bone loss in castrated male mice and growing male mice respectively (Fujioka et al., 2007; Ishimi et al., 2002; Khalil et al., 2005). Under such background, a new snack was developed by use of black soybean. The amount of isoflavone in this snack was determined with a special reference to the amount of safety surplus nutrition per day defined by MHLW.

Decrease in the trabecular and cortical bone volumes after gonadectomy has already been demonstrated by our previously reports (Fujita et al., 2001, 2004). We also reported that bone growth was significantly suppressed in the gonadectomized mice immediately after birth (Fujita et al., 2006). Moreover, we clarified that decrease in bone volume was occurred four weeks after gonadectomy. According to these results, we examined bone density of the femur six weeks after ovariectomy and orchiectomy.

The density of trabecular and cortical bones in the gonadectomized mice given LCD was significantly lower than in the sham operated mice given NCD and LCD, respectively. It was revealed that the deficiency of calcium intake caused decrease in bone density, under sex hormone disturbances in particular. Therefore, it is speculated that the bone density is below the optimal level in Japanese and fracture risk may become higher for aged people. These findings also support that the incidence of primary osteoporosis is higher in Japan than in American and European countries.

The bone metabolism is classified into two types, high turnover type to accelerate both bone formation and resorption and low turnover type caused by degradation of bone formation. In this study, twelve-week-old mice with sham operation fed LCD are regarded as young growing humans with low turnover type, whereas gonadectomy mice to simulate sex hormone disturbance in the experimental groups are assumed to be under the condition of 
postmenopausal osteoporosis as a high turnover type. Irrespective of the turnover types, however, the bone density in the group 5 given appropriate amount of calcium by supplying SCD exhibited a remarkable increase. It is thus suggested that sufficient calcium quantity through nutrition of newly developed bean snack enhanced bone formation irrespective of age.

It is reported that postmenopausal women with daily calcium intake of less than $400 \mathrm{mg}$ experience significant bone loss and that calcium intake of $800 \mathrm{mg}$ per day is effective for improving postmenopausal bone loss (Dawson-Hughes et al., 1990; Reid et al., 1993). On the other hand, it is well known that improvement effect against bone volume loss by calcium intake is available only at the initial stage of treatment. In addition, Riggs et al., clarified that the effect on bone loss is weaker than those reported for estrogen and bisphosphonates therapy, indicating that calcium supplements alone can't substitute treatment for osteoporosis (Riggs et al., 1998). In this study, longitudinal effect of newly developmental snack intake was not examined. However, It is hopefully anticipated that new bean snack could contributed to the enrichment of QOL as a nutrition function food, because of it was contain of several ingredients to promote assimilation efficiency of calcium.

\section{Conclusions}

The new snack we developed included proper amount of calcium, magnesium, CPP and black soybean. When this product was given to the osteoporosis model mice, bone density of the femur was significantly increased. From these results, it is suggested that this product supplement promote bone formation irrespective of gender and age. We demonstrated that newly developmental snack supplements may be a useful preventive measure for the people whose bone mineral density values are less than the ideal condition.

\section{Acknowledgement}

This investigation was supported by Grants-in Aid for Scientific Research of the Ministry of Education, Culture, Sports, Science and Technology in Japan (19890131) and Hiroshima University collaborative research (052010).

\section{References}

Judd, H. L., Meldrum, D. R., Deftos, L. J., \& Henderson, B. E. (1983). Estrogen replacement therapy: indications and complications. Annual of Internal Medicine, Vol. 98, No. 2, (February 1983), pp. 195-205, ISSN 1539-3704

Kousteni, S., Chen, J., Bellido R. T., Han, L., Ali, A. A., O'Brien, C. A., Plotkin, L., Fu, Q., Mancino, A. T., Wen, Y., Vertino, A.M., Powers, C.C., Stewart, S.A., Ebert, R., Parfitt, A.M., Weinstein, R.S., Jilka, R.L., \& Manolagas, S.C. (2002). Reversal of bone loss in mice by nongenotropic signaling of sex steroids. Science, Vol. 298, No. 5594, (February 2003), pp. 843-846, ISSN 1095-9203

Martin-Milan, M., Almeida, M., Ambrogini, E., Han, L., Zhao, H., Weinstein, R. S., Jilka, R. L., O'Brien, C. A., \& Manolagas, S. C. (2010). The estrogen receptor-alpha in osteoclasts mediates the protective effects of estrogens on cancellous but not 
cortical bone. Molecular endocrinology, Vol. 24, No. 2, (January 2010), pp. 323-334, ISSN 0888-8809

Pietschmann, P., Rauner, M., Sipos, W., \& Kerschan-Schindl, K. P. (2008). Osteoporosis: an age-related and gender-specific disease: a mini-review. Gerontology, Vol. 55, No. 1, (October 2008), pp. 3-12, ISSN 1423-0003

Chang, K. P., Center, J. R., Nguyen, T. V., \& Eisman, J. A. (2004). Incidence of hip and other osteoporotic fractures in elderly men and women: Dubbo Osteoporosis Epidemiology Study. Journal of Bone and Mineral Research, Vol. 19, No. 4, (January 2004), pp. 532-536 ISSN 1523-4681

O'Neill, T. W., Felsenberg, D., Varlow, J., Cooper, C., Kanis, J. A., \& Silman, A. J. (1996). The prevalence of vertebral deformity in european men and women: the European Vertebral Osteoporosis Study. Journal of Bone and Mineral Research, Vol. 11, No. 7, (December 2009), pp. 1010-1018, ISSN 1523-4681

Fujita, T., Kawata, T., Tokimasa, C., \& Tanne, K. (2001). Influence of oestrogen and androgen on modelling of the mandibular condylar bone in ovariectomized and orchiectomized growing mice. Archives Oral Biology, Vol. 46, No. 1, (January 2001), pp. 57-65, ISSN 1879-1506

Fujita, T., Ohtani, J., Shigekawa, M., Kawata, T., Kaku, M., Kohno, S., Tsutsui, K., Tenjo, K., Motokawa, M., Tohma, Y., \& Tanne, K. (2006) Effects of sex hormone disturbances on craniofacial growth in newborn mice. Journal of Dental Research, Vol. 83, No. 3, (January 2004), pp. 950-254, ISSN 1554-0591

Orimo, H. (2001) New diagnostic criteria of primary osteoporosis. Clinical Calcium, Vol. 11, No. 9, (September 2001), pp. 1133-1139. ISSN 20010917-5857

Lapauw, B., Taes, Y., Bogaert, V., Vanbillemont, G., Goemaere, S., Zmierczak, H., De Bacquer, D., \& Kaufman, J. (2009). Serum estradiol is associated with volumetric bone mineral density and modulates the impact of physical activity on bone size at the age of peak bone mass; a study in healty male siblings. Journal of Bone and Mineral Research, Vol. 24, No. 6, (December 2008), pp. 1075-1085, ISSN 1523-4681

Karlsson, M. K., Nordqvist, A., \& Karlsson, C. (2008). Physical activity increase bone mass during growth. Food and Nutrition Research, Vol. 52 doi: 10.3402/fnr.v52i0.1871. (October 2008), ISSN 1654-661X

Wang, Q., \& Seeman, E. (2008). Skeletal growth and peak bone mass. Best Practice and Research. Clinical Endocrinology and Metabolism, Vol. 22, No. 5, (October 2008), pp. 687-700, ISSN 1532-1908

Rosen, C. J., \& Gallagher, J. C. (2011). The 2011 IOM report on vitamin D and calcium requirements for north America: clinical implications for providers treating patients with low bone mineral density. Journal of Clinical Densitometry, Vol. 14, No. 2, (April 2011), pp. 79-84, ISSN 1094-6950

Schoenau, E., \& Fricke, O. (2008). Mechanical influences on bone development in children. European Journal of Endoclinology, Vol. 159, No. 1, (September 2008), pp. 27-31 ISSN 1479-683X

Yamada, K., Sato-Mito, N., Nagata, J., \& Umegaki, K. (2008). Health claim evidence requirements in Japan. Journal of Nutrition, Vol. 138, No. 6, (January 2008), pp. 1192S-8S ISSN 1541-6100 
Kim, Y. K., Wassef, L., Chung, S., Jiang, H., Wyss, A., Blaner, W. S., \& Quadro, L. (2011). Beta-carotene and its cleavage enzyme beta-carotene-15, 15'-oxygenase (CMOI) affect retinoid metabolism in developing tissues. Official Publication of the Federation of American Societies for Experimental Biology, Vol. 25, No. 5, (May 2011), pp. 16411652, ISSN 1530-6860

Mueller, L., \& Boehm, V. (2011). Antioxidant activity of beta-carotene compounds in different in vitro assays. Molecules. Vol. 25, No. 16, (January 2011), pp. 1055-69 ISSN 1420-3049

Skulan, J. \& DePaolo, D. J. (1999). Calcium isotope fractionation between soft and mineralized tissues as a monitor of calcium use in vertebrates. Proceedings of the National Academy of Sciences of the United States of America, Vol. 96, No. 24, (November 1993), pp. 13709-13713, ISSN 1091-6490

Reynolds, E. C. (2009). Casein phosphopeptide-amorphous calcium phosphate: the scientific evidence. Advances in Dental Research, Vol. 21, No. 1, (August 2009), pp. 25-29, ISSN 1544-0737

Llena, C., Forner, L., \& Baca, P. (2009). Anticariogenicity of casein phosphopeptideamorphous calcium phosphate: a review of the literature. Journal of Contemporary Dental Practice, Vol. 10, No. 3, (May 2009), pp. 1-9, ISSN 1602-1622

Andersson, A., Sköld-Larsson, K., Hallgren, A., Petersson, L. G., \& Twetman, S. (2007). Effect of a dental cream containing amorpous complexs on white spot lesion regression assessed by laser fluorescence. Oral Health and Preventive Dentistry, Vol. 5, No. 3, (January 2007), pp. 229-233, ISSN 1602-1622

Morgan, M. V., Adams, G. G., Bailey, D. L., Tsao, C. E., Fischman, S. L., \& Reynolds, E. C. (2008). The anticariogenic effect of sugar-free gum containing CPP-ACP nanocomplexes on approximal caries determined using digital bitewing radiography. Caries Research, Vol. 42, No. 3, (April 2008), pp. 171-184, ISSN 1421976X

Zhang, Q., Zou, J., Yang, R., \& Zhou, X. (2011). Remineralization effects of casein phosphopeptide-amorphous calcium phosphate crème on artificial early enamel lesions of primary teeth. International Journal of Pediatric Dentistry, Vol. 21, No. 5, (January 2011), pp. 374-381, ISSN 1365-263X

Altenburger, M. J., Gmeiner, B., Hellwig, E., Wrbas, K. T., \& Schirrmeister, J. F. (2010). The evaluation of fluorescence changes after application of casein phosphopeptides (CPP) and amorphous calcium phosphate (ACP) on early carious lesions. American Journal of Dentistry, Vol. 23, No. 4, (August 2010), pp. 188-192, ISSN 0894-8275

Woo, J., Kwok, T., Leung, J. C., Ohlsson, C., Vandenput, L., \& Leung, P. C. (2011). Sex steroids and bone health in older Chinese men. Osteoporosis International, doi: 10.1007/ s00198-001-1552-y

Moayyeri, A., Kaptoge, S., Luben, R. N., Wareham, N. J., Bingham, S., Reeve, J., \& Khaw, K. T. (2009). Estimation of absolute fracture risk among middle-aged and older men and women: the EPIC-Norfolk population cohort study. European Journal of Epidemiology, Vol. 24, No. 5, (April 2009), pp. 259-266 ISSN 1573-7284

Mora, S., \& Gilsanz, V. (2003). Establishment of peak bone mass. Endocrinology and Metabolism Clinics of North America, Vol. 32, No. 1, (March 2003), pp. 39-63, ISSN $1558-4410$ 
Dontas, I. A., \& Yiannakopoulos, C. K. (2007). Risk factors and prevention of osteoporosisrelated fractures. Journal of musculoskelet Neuronal Interact, Vol. 7, No. 3, (September 2009), pp. 268-272, ISSN 1108-7161

Brandi, M. L. (2003). Management of post-menopausal osteoporosis: something new on the horizon?. Journal of Endocrinology Investigation, Vol. 26, No. 2, (Feburary 2003), pp. 170-173, ISSN 1720-8386

Miyauchi, A., Notoya, K., Taketomi, S., Takagi, Y., Fujii, Y., Jinnai, K., Takahashi, K., Chihara, K., \& Fujita, T. (1996). Novel ipriflavone receptors coupled to calcium influx regulate osteoclast differentiation and function. Endocrinology, Vol. 137, No. 8, (August 1996), pp. 3544-3550, ISSN 1945-7170

Chavarro, J. E., Toth, T. L., Sadio, S. M., \& Hauser, R. (2008). Soy food and isoflavone intake in relation to semen quality parameters among men from an infertility clinic. Human Reproduction, Vol. 23, No. 11, (November 2008), pp. 2584-2590, ISSN 14602350

Fujioka, M., Sudo, Y., Okumura, M., Wu, J., Uehara, M., Takeda, K., Hosokawa, Y., Yamada, K., Ikegami, S., \& Ishimi, Y. (2007). Differential effects of isoflavones on bone formation in growing male and female mice. Metabolism Clinical and Experiment, Vol. 56, No. 8, (August 2008), pp. 1142-1148, ISSN 1532-8600

Ishimi, Y., Yoshida, M., Wakimoto, S., Wu, J., Chiba, H., Wang, X., Takeda, K., \& Miyaura, C. (2002). Genistein, a soybean isoflavone, affects bone marrow lymphopoiesis and prevents bone loss in castrated male mice. Bone, Vol. 31, No. 1, (July 2002), pp. 180185, ISSN 1873-2763

Khalil, D. A., Lucas, E.A., Smith, B. J., Soung, D. Y., Devareddy, L., Juma, S., Akhter, M. P., Recker, R., \& Arjmandi, B. H. (2005). Soy isoflavones may protect against orchidectomy-induced bone loss in aged male rats. Calcified Tissue International, Vol. 76, No. 1, (January 2005), pp. 56-62, ISSN 1432-0827

Fujita, T., Kawata, T., Ohtani, J., Kaku, M., Tokimasa, C., Kohno, S., Tsutsui, K., Tenjo, K., Motokawa, M., \& Tanne, K. (2001). Breadth of the mandibular condyle affected by disturbances of the sex hormones in ovariectomized and orchiectomized mice. Clinical Orthodontic Research, Vol. 4, No. 3, (August 2001), pp. 291-294, ISSN 16000544

Fujita, T., Ohtani, J., Shigekawa, M., Kawata, T., Kaku, M., Kohno, S., Motokawa, M., Tohma, Y., \& Tanne, K. (2006). Influence of sex hormone disturbances on the internal structure of the mandible in newborn mice. European Journal of Orthodontics, Vol. 28, No. 2, (April 2006), pp. 190 193, ISSN 1460-2210

Fujita, T., Ohtani, J., Shigekawa, M., Kawata, T., Kaku, M., Kohno, S., Tsutsui, K., Tenjo, K., Motokawa, M., Tohma, Y., \& Tanne, K. (2006). Effects of sex hormone disturbances on craniofacial growth in newborn mice. Journal of Dental Research, Vol. 83, No. 3, (March 2006), pp. 250-254, ISSN 1544-0591

Dawson-Hughes, B., Dallal, G. E., Krall, E. A., Sadowski, L., Sahyoun, N., \& Tannenbaum, S. (1990). A controlled trial of the effect of calcium supplementation on bone density in postmenopausal women. The New England Journal of Medicine, Vol. 323, No. 13, (September 1990), pp. 878-883, ISSN 1533-4406 
Reid, I. R., Ames, R. W., Evans, M. C., Gamble, G. D., \& Sharpe, S. J. (1993). Effect of calcium supplementation on bone loss in postmenopausal women. The New England Journal of Medicine, Vol. 328, No.7, (February 1993), pp. 460-464, ISSN 1533-4406

Riggs, B. L., O'Fallon W. M., Muhs, J., O'Connor M. K., Kumar, R., \& Melton L. J. (1998). Long-term effects of calcium supplementation on serum parathyroid hormone level, bone turnover, and bone loss in elderly women. Journal of Bone and Mineral Research, Vol. 13, No. 2, (February, 1998), pp. 168-174, ISSN 1523-4681 


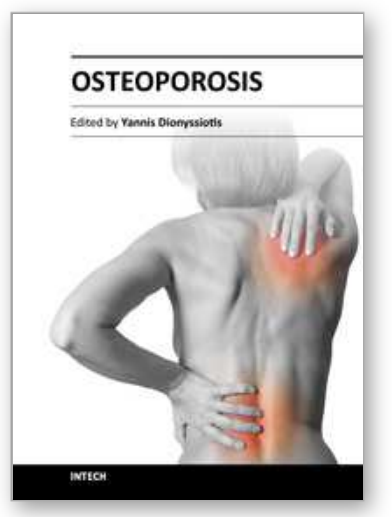

\author{
Osteoporosis \\ Edited by PhD. Yannis Dionyssiotis
}

ISBN 978-953-51-0026-3

Hard cover, 864 pages

Publisher InTech

Published online 24, February, 2012

Published in print edition February, 2012

Osteoporosis is a public health issue worldwide. During the last few years, progress has been made concerning the knowledge of the pathophysiological mechanism of the disease. Sophisticated technologies have added important information in bone mineral density measurements and, additionally, geometrical and mechanical properties of bone. New bone indices have been developed from biochemical and hormonal measurements in order to investigate bone metabolism. Although it is clear that drugs are an essential element of the therapy, beyond medication there are other interventions in the management of the disease. Prevention of osteoporosis starts in young ages and continues during aging in order to prevent fractures associated with impaired quality of life, physical decline, mortality, and high cost for the health system. A number of different specialties are holding the scientific knowledge in osteoporosis. For this reason, we have collected papers from scientific departments all over the world for this book. The book includes up-to-date information about basics of bones, epidemiological data, diagnosis and assessment of osteoporosis, secondary osteoporosis, pediatric issues, prevention and treatment strategies, and research papers from osteoporotic fields.

\title{
How to reference
}

In order to correctly reference this scholarly work, feel free to copy and paste the following:

Junji Ohtani, Fujita Tadashi, R.A. Marquez Hernandez, Toshitsugu Kawata, Masato Kaku, Masahide Motokawa and Kazuo Tanne (2012). Nutrition for Enhancing Bone Volume in Mice, Osteoporosis, PhD. Yannis Dionyssiotis (Ed.), ISBN: 978-953-51-0026-3, InTech, Available from:

http://www.intechopen.com/books/osteoporosis/nutrition-for-enhancing-bone-volume-in-mice

\section{INTECH}

open science | open minds

\section{InTech Europe}

University Campus STeP Ri

Slavka Krautzeka 83/A

51000 Rijeka, Croatia

Phone: +385 (51) 770447

Fax: +385 (51) 686166

www.intechopen.com

\section{InTech China}

Unit 405, Office Block, Hotel Equatorial Shanghai

No.65, Yan An Road (West), Shanghai, 200040, China

中国上海市延安西路65号上海国际贵都大饭店办公楼405单元

Phone: $+86-21-62489820$

Fax: +86-21-62489821 
(C) 2012 The Author(s). Licensee IntechOpen. This is an open access article distributed under the terms of the Creative Commons Attribution 3.0 License, which permits unrestricted use, distribution, and reproduction in any medium, provided the original work is properly cited. 